\title{
Content Analysis of Microstructure of Oxford English Sindhi-Dictionary 2010
}

\author{
Jamil Ahmed \\ MS Scholar ELDC Mehran University of Engineering and Technology \\ Dr. Ambreen Shahriar \\ Associate Professor IELL University of Sindh Jamshoro \\ Sadia Inayat \\ Lecturer English ELDC Mehran University of Engineering and Technology
}

\begin{abstract}
The aim of this research was to critically analyze the microstructure of the oxford English Sindhi dictionary (2010). In order to achieve the aim of the study, an objective was set to find out the way information was presented in the microstructure of OESD (2010) which was the sample of the study. Afterwards, the study was designed qualitatively as per the nature of the study and it was decided after going through a huge corpora related to critical dictionary analysis. The dictionary was analyzed through content analysis. This required a sample to be selected and taken from every twentieth page of the dictionary. The results of the study were discussed descriptively. The results of the study showed that there was a lot of information present in the microstructure of the dictionary. This information was related to meaning, labels including word class, symbols, abbreviations etc. It also included pronunciation of words. First of all meaning was present at lexical level and in the form of definitions. Secondly, the word class of the entries was also given in front of them. Moreover, abbreviations and acronyms were also present in the microstructure but these were not differentiated from each other. Most importantly, certain phonemes were presented in a wrong way. That is to say the symbols which were given for the sounds did not represent the actual sounds of the given words. This was found to be one of the mistakes which might have taught the learners wrong pronunciation of the words.
\end{abstract}

Keywords: lexicography, microstructure, dictionary, critical dictionary analysis, OESD (2010).

DOI: $10.7176 /$ RHSS/10-3-04

Publication date: February $29^{\text {th }} 2020$

\subsection{INTRODUCTION}

In ESL/EFL countries like Pakistan where language is learned through the set of rules and tools provided to them like, Grammar books and Dictionaries, bi-lingual dictionaries, there it is considered as reliable source of vocabulary building and most helpful tool. Bilingual dictionaries are bi-directional they go from one direction i.e. from English to Another language. Bilingual dictionaries provide equivalent of source language in target language. EFL/ ESL Readers are left with only two choices to understand the meaning of text they are dealing with, by using dictionaries or going through context. The efficient readers prefer the use of dictionaries despite of going through the context. "It is estimated that vocabulary learning from context is only possible and reliable when the student understands between $95 \%$ and $98 \%$ of the text" (Laufer 2005).

Dictionary is considered a well set and well-arranged list of lexemes that the speakers of a language use in their context of interaction. It helps a learner practically and according to Dash.N.S (2005) language learners consult it to gain information related to a lexeme. This information includes meaning, origin, usage and pronunciation of that particular word.

Additionally, Zgusta (1971) provides that a dictionary is a systemized list of lexemes. It is arranged based on the social uses of those lexical items in a particular context of their use. These lexical items are mainly compiled by lexicographers from the way these are used by speech communities. These are arranged separately so that the learner may come to know about them easily through a dictionary.

\subsection{Structure of Dictionary}

The structure mainly shows the components of a dictionary. It also represents the way a dictionary is designed: it shows its whole structure. Three terms are usually used to describe the structure of a dictionary as per Meta lexicography. These terms are: Mega-structure, Macro-structure and Micro-structure. 


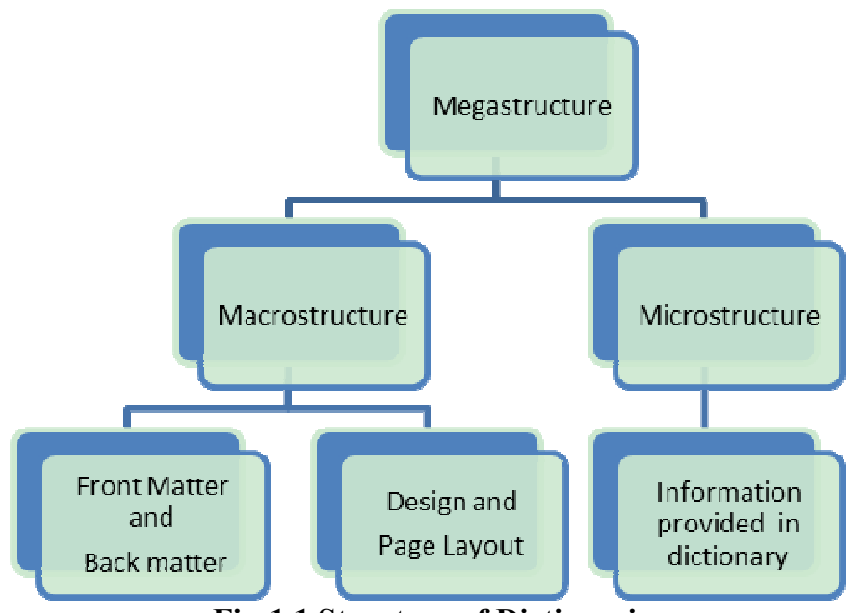

Fig:1.1 Structure of Dictionaries

\subsection{Synchronic and diachronic development of English Sindhi Dictionaries}

Historical and synchronic are defined by Pearsall.j (2015). Synchronic study of a dictionary is defined as the study which is done at a particular time. Contrastingly, the diachronic dictionary approach is related to the study of language throughout time.

Shah Zulfiqar and Soomro Ashfaque (2016). Since the early period of British rule over Sindh, a good work has been done in dictionary making in Sindhi in order to make the native people familiar with English language. Two massive works appeared in this period i.e. English-Sindhi and Sindhi-English dictionaries. In 1849, the English-Sindhi Dictionary published from Bombay was compiled by Captain George Stack, a Deputy Collector of Hyderabad and the was edited by Sir Barrow Ellis in the year 1855. The script used in the compilation of both of these dictionaries was Devnagri. an English man Mr. Shirt and two Sindhi scholars M/s. Udha Ram Thanwardas and Mirza Sadiq Ali Beg conjointly compiled Sindhi-English Dictionary (1879)- the first immense work in bilingual dictionary in Sindhi lexicography. The script the dictionary published in was Arabic-Sindhi script and this was first in this script as prior to this dictionary, no other dictionary was published in ArabicSindhi script.

If we trace the Sindhi lexicographic work before and after the creation of Pakistan. There are two significant dictionaries compiled before Pakistan, Permanand Mewaram's English-

Sindhi Dictionary (1933) and an other was by Anandram T. Shahani (1939). Many Lexicographers put a lot of their efforts into this field. Some of them are as: Abdul Na Pirzado (2007), Abdul Rashid Memon (2007), Bashir Mangi (2006), Abdul Hussain Memon (1959), Ghulam Mustafa Shah(1972), Ali Dino Shah.

After the independence, the first two are held among the pioneers of the English-Sindhi Bilingual lexicography. Furthermore, online and paper dictionaries are compiled and published by Sindhica Academy, Oxford university press Karachi and Sindhi Language Authority Hyderabad Sindh Pakistan.

\subsection{Research Question}

The current study will be followed by these two important questions.

1. How the information contained in microstructure is presented in OESD (2010)?

\section{2 .0 LITERATURE REVIEW}

A research was conducted in the field of Lexicography in 2015 by Mgr.Zuzana Cechova the research analyze the micro structure of English language dictionaries, Cambridge Advanced Learner's Dictionary, Oxford Advanced Learner's Dictionary and The Co build English for Learners Dictionary. 11 groups of words have been selected to analyze: Abstract, concrete, countable and uncountable//// nouns, adjectives derived from verbs, adverbs, irregular verbs, words that differ in English and American pronunciation. The findings of study reveals that the OALD is very precise in the definition and divides the senses according to slight differences in meaning, in comparison with the CALD or the Co build Dictionary. The definitions in the CALD are more general and they give more senses which are introduced separately in the OALD. Regarding the pronunciation researcher founds that all the three dictionaries provide difference in American and British pronunciation. Co build dictionary has no stress markers in the transcription of pronunciation resultantly this brings ambiguity for nonnative speakers of English. After analyzing above mentioned dictionaries researcher recommended Cambridge Advanced Learner's Dictionary as helpful for learners.

Another research was done in 2016 (Shah.Z and Soomro.A). The researcher selected eight (08) bilingual 
English to Sindhi dictionaries listed below:

English and Sindi Dictionary, by Lakshuman Vishnu Parajpye (1868),

English-Sindhi Dictionary, by Nanikram D. Mirchnadani (1928),

English-Sindhi Dictionary, by Dulamal Bulchand (1928),

A New English-Sindhi Dictionary By: Permanand Mewaram (1933),

English to Sindhi Dictionary, by Anandram T. Shahani (1939-41),

Sindhica: English to Sindhi Dictionary (2003),

Advanced Dictionary: English to English and Sindhi, by Abdul Nabi Pirzada,

Oxford English-Sindhi Dictionary (2010).

Method of investigation is content analysis. The paper provides general overview of meaning and pronunciation presented in English to Sindhi dictionaries. Researcher explores that all the dictionaries included in study provide good deal of meaning but most of the dictionaries lack pronunciation, grammatical information and usage.

Similar research was conducted on presenting pronunciation in English to Sindhi bilingual dictionary in 2015 by (Shah.Z and Mashori.G). This research studied all the six dictionaries that include pronunciation in them. It was a diachronic study pronunciation based dictionaries. It included the following dictionaries:

English Sindhi Dictionary by Anandram T. Shahani (1939)

Yadgar Dictionary Shah, A. D \& Mangi, B. A (1988)

Sindhica English-Sindhi published by Sindhica Academy, Karachi (2003).

Kifayat's English to English and Sindhi Dictionary by Rashid Ahmed Memon (2004).

Advanced Dictionary: English to English and Sindhi by Abdul Nabi Pirzado (2007)

Oxford English to Sindhi dictionary by Shah. Q \& Abro. B (2010)

Content analysis is employed as research method. The Researchers have concluded that only Shahni has used the diacritic marks to help the learners to master pronunciation. According to them such usage of the diacritic marks has made it effective in learning English pronunciation. Moreover, other five dictionaries are full of blunders and do not provide accurate pronunciation. Oxford English-Sindhi dictionary use software to read the IPA pronunciation in which translation is converted automatically in pronunciation. It may be software problem which commits mistakes in pronunciation. Furthermore researcher has concluded that there isn't any English to Sindhi dictionary which provides authentic pronunciation.

\subsection{METHODOLOGY}

This study is mainly qualitative in nature. In critical dictionary research the researcher had employed content analysis to accomplish the set goals. It was because, according to Cohen, Manion,; \& Morrison, (2009), Scott (2006) and Julien (2008) content analysis as a method of qualitative research is mainly used for textual investigation.

In Content analysis a text is closely and critically analyzed by examining what it contains. Julien (2008) provides that different instances may be provided by the identified categories of the data. Through this analysis one can ensure whether certain elements are present in the provided document. After the classification of the categories, the researcher made an attempt to ensure whether the data is categorically comprehensive and well defined (Julien, 2008). The researcher through this analysis tried to confirm the covered components in the microstructure of the selected dictionary. Furthermore, the researcher confirmed how the pronunciation is presented through IPA. Additionally, the meaning equivalents were also checked, by checking the way it was presented in the dictionary..

\subsection{FINDINGS AND DISCUSSIONS}

The data presented in this section is taken from the oxford English Sindhi dictionary 2010. This section provides a clear picture of the data related to the findings. In short, it provides the reader with the knowledge related to the way dictionary was analyzed and the findings which emerged after its analysis. It also includes in it discussions which shall clarify the terms, figures and tables which are given in certain sections.

This research is related to the way entries are presented in the dictionary. The researcher analyzed the way the identified information is presented in the dictionary. The analysis related to these entries has been discussed in this section. Moreover, there is a separate heading related to the representation of pronunciation of head words. The pronunciation, which has been done in IPA, of English words has been compared with its equivalent which is in OALD $9^{\text {th }}$ ed. the analysis has been given in this following sub-sections.

\subsection{Meaning}

Presenting meaning in a bilingual dictionary is most important part of the dictionary making. A complier has to deal with two different languages. There are two types of meaning presentation in bilingual dictionary by providing lexical equivalent and other is giving definitions (shah 2012). The dictionary under the study presents 
both lexical/ one word equivalent and definitions. Additionally, connotations and polysemous meanings are also provided in dictionary. Some examples which the researcher found during analysis are given below:

\section{a Lexical equivalent}

Table 4.1: Lexical Equivalent, From Oxford English Sindhi Dictionary 2010.

\begin{tabular}{|c|c|c|}
\hline Page No. & Word & Meaning \\
\hline 144 & Ballot Paper & ووتث جي يرجي \\
\hline 1082 & Mechanic & مشين جو مستري \\
\hline 1156 & Naturally & فطري طور \\
\hline 1642 & Sip & بك \\
\hline
\end{tabular}

b Definitions

Table 4.2: Definitions From Oxford English Sindhi Dictionary 2010.

\begin{tabular}{|c|c|c|}
\hline Page No. & Word & Definition \\
\hline 105 & Augustan & رومي شهنشاه آكسنّس يا سندس دور متعلق خاص كري لاطيني ادب جي سونهري دور طور \\
\hline 584 & Episcope & غير شفاف شين كي ظاهر كري بيكاريندز" \\
\hline 22 & Adivasi & هندستان جو اصلوكو قبيلو \\
\hline 1802 & Taoism & 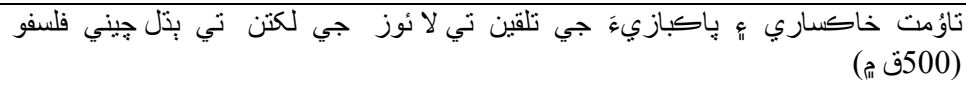 \\
\hline
\end{tabular}

\section{Discussion}

Meaning in this dictionary is presented as clear as possible both denotatively as well as connotatively. As far as the examples related to denotative meaning are concerned, some of them have been quoted above. Moreover,

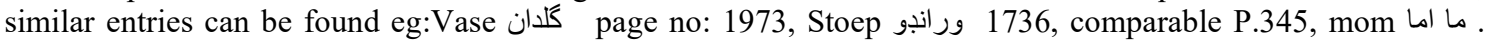
Secondly, connotative meanings are also provided for example lion P.1020 بهادر شخص، دلير ، سور هيه: Additionally, similar kind of words can be found beast P.142. The complier has presented meaning in one or two words. Moreover, definition method has also been employed for words which cannot be explained in one word. Some of the examples related to such entries are given above. Other examples related to this entry can be found: Drachm P.522, Ergative P. 587, Hedonism P.813, Leopard P.1003. If one turns towards the definitions provided in dictionary, these definitions are precise and authentic. Other than the above discussed entries that have only one of these like certain entries have only denotative meaning, certain have only connotative meaning. But, despite these, there were certain entries that had connotative meaning, denotative meaning, idiomatic usages and their use in different linguistic contexts. In this case there was an entry e.g. Heart which have three connotations and 25 idioms, see Break on page number 203 , burn page number 224, Go. page number 746 to 748 are translated in Sindhi throughout the dictionary. These meanings are numbered separately to facilitate and to overcome the ambiguity for learner. That numbering represents meaning of a word. For example if a word has three meaning then each meaning has been written with a number. The drawback of such representation of words is that the meaning of such words which have more than one meaning, has been represented in paraphrased version. Furthermore, register based jargon meanings are also provided in entry see Radical on page no. 1430. The connotations are presented mostly in Sindhi part of the dictionary, rarely in English, throughout the dictionary.

\subsection{Labeling}

As far as labeling in this dictionary is concerned, the entries in this connection have been labeled with the part of speech to which the entries belongs. Another type of labeling is related to the usage of the word in its different linguistic contexts. Cross-references related to the entry are also given. In addition, etymology of that entry is also given as a label. Finally the word contains certain notes which help the learner to know the use of that lexical item.

\section{a Word class}

The word classes are mentioned in front of every word eg aright/ adv P 86, . Moreover, how a single word is being used in different word classes. For example, sometimes it is used as a noun, whereas it does have certain forms in which it becomes a verb or adjective eg. Duplex/ noun. \& adj P. 539, crash/ $v ., n . \&$ adv, m. Dear Adjective: صفت , حرف ندا , : ظرف : In order to tell the learner about the word class of that particular word, its different forms with its respective word classes are also given in the entry. An entry in this connection, particularly its head word possesses its class in word class in English, whereas the classes of its other forms are given in Sindhi language.

\section{b Morphological representation}

In the dictionary the inflectional and derivational morphemes of a head word are also given in the explanatory section of an entry. For instance, what inflectional morphemes are inflected to a word and what sort of derivations are connected to change its word class. Moreover, the derivations are also given in dictionary as separate entries. Some of the examples are; Suffix: p.115. Ed: in Talented ركدزّ ، متاثر ثثيل ، بهريل وغيره , اسمن مان 


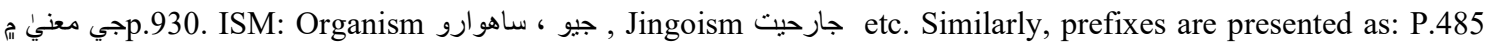

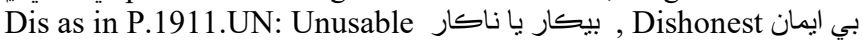

c Usage

The usage of the words in the dictionary is given in brackets which are given below the meaning of an entry. It follows examples related to the usage of that head-word. Moreover, in the usage section, it had also been discussed whether the word is being used transitively or intransitively. It also includes the structural formation of

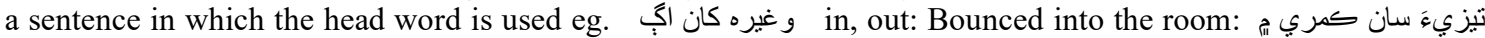

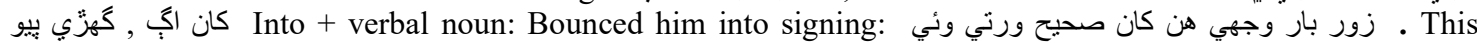
structural formation also tells the learner about the neighboring structures, including its colloquial, which are used with the word, for example whether a word follows a 'that clause' or not. In addition, the varietal differences of the word, that is to say its usage, in its different varieties of English, is also given in the dictionary, for example Pinole P.1319 : As far the functional use of the entry is concerned, the dictionary also teaches a learner the way a word is used in different ways like informal, formal, slang etc. In simple words the dictionary provides information related to the use of a head word in different registers. For instance. P. 77 Appeal: in Law كنهن كيس جي اكلاءَ لاءٍ اعلى عدالت

ـ ذّانهن رجوع، In addition to the above points, the geographical location, on the basis of a word's usage, has also been given in the entries. It means like in what places the word is being used. Such usage refers to the linguistic map of the world.

dUsage notes

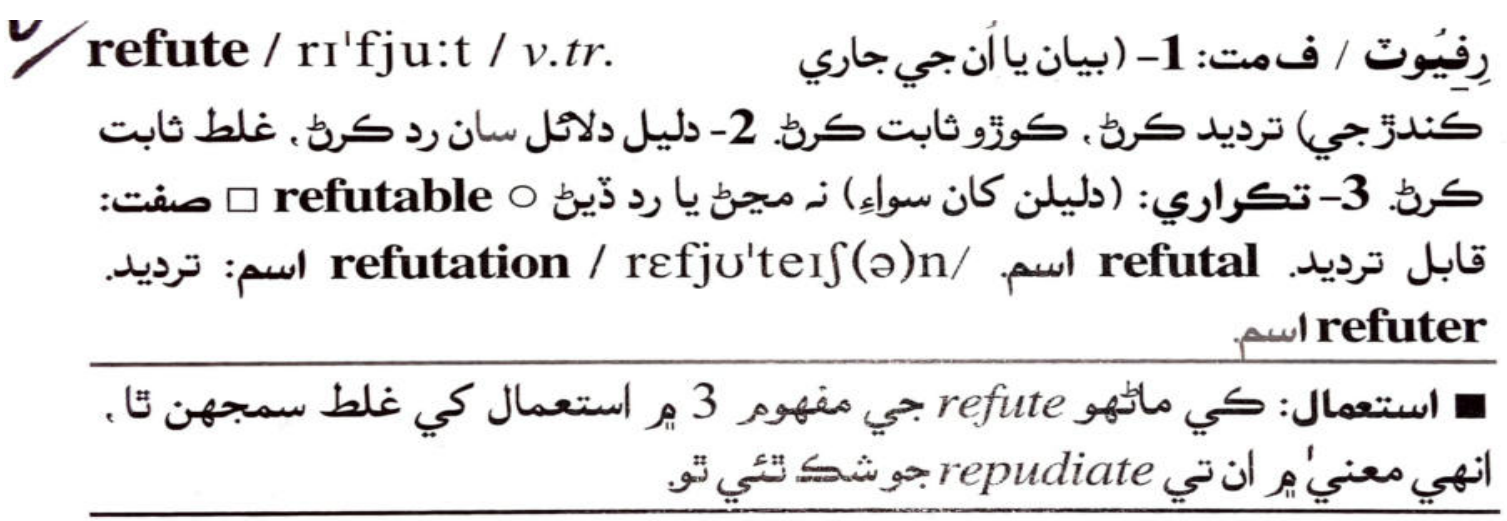

Figure 4.1: Image from Oxford English Sindhi Dictionary 2010 ( Usage Note)

\section{Discussion}

In addition to the above given labels, an additional point in an entry is of usage notes. This is different from the usage which has already been discussed above. These usage notes are given in parenthesis in an entry whereever necessary. The usage notes provide the learner the information related to the use of a word in a particular context or domain. The usage notes are not similar to its definitions. The usage notes restrict the definition of a word to a certain domain. The domains of usage vary word to word, as it is quite clear that a word might belong to a standard variety or a non-standard variety of a language.

\section{e SYMBOLS AND ABBREVIATIONS}

This dictionary contains symbols and abbreviations as separate entries. The symbols are mostly related to

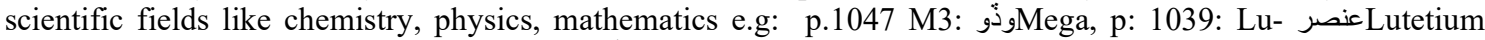

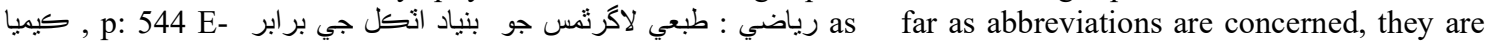
related to medical, social, academic, scientific, organization related, food, news agency, tools, ranks and some of them are related to different professions as well e.g: EVA: Extra vehicular Activity: هو ا بازي م, BCG: Bacillus calmete Guerin: سله جي بيماري جا حفاظتي نكا It was also found during the analysis that there were certain abbreviated forms in English that do not have their meaning equivalents, definitions or explanations in Sindhi language. Most importantly, the OESD has used their system of abbreviations; a very considerable defect is acronyms are also labeled as abbreviations e.g. UNICEF, NEPRA. Whereas, acronyms are the words that are formed with the initials of words that makeup name of something (OALD $9^{\text {th }}$ ed.)

\subsection{Pronunciation}

As discussed earlier the pronunciation in the dictionary was found to be having problems in it. That can be defined in a way that the given phonemes do not represent the actual sounds of certain word. The extracted data related to such finding has been given below in the table. 
Table 4.3.1: Pronunciation. Comparison of examples from Oxford English Sindhi Dictionary 2010 and Oxford Advanced learners dictionary.

\begin{tabular}{c|c|c|c} 
Word & Pronunciation in Sindhi & $\begin{array}{c}\text { IPA transcription given } \\
\text { Oxford English Sindhi } \\
\text { Dictionary 2010 }\end{array}$ & $\begin{array}{c}\text { transcription given in } \\
\text { OALD 9 }\end{array}$ \\
\hline Admiral Edition
\end{tabular}

Instead of using monophthong open mid front/æ/ in the words like bank, the dictionary provides monophthong open front $/ \mathrm{a} /$.

Table 4.3.2. Pronunciation. Examples from Oxford English Sindhi Dictionary 2010 and Oxford Advanced learners dictionary.

\begin{tabular}{|c|c|c|c|}
\hline Word & $\begin{array}{c}\text { Pronunciation in } \\
\text { Sindhi }\end{array}$ & $\begin{array}{l}\text { IPA transcription given } \\
\text { Oxford English Sindhi } \\
\text { Dictionary } 2010 \\
\end{array}$ & $\begin{array}{l}\text { transcription given in } \\
\text { OALD } 9^{\text {th }} \text { Edition }\end{array}$ \\
\hline Bird & No pronunciation & / bə:d / & / b3:d / \\
\hline Girl & ك' & / gə:1 / & / g3:1/ \\
\hline Whirl & وَل & /wa:1/ & /w3:1/ \\
\hline Pearl & بَلِل & / po:1/ & / p3:1/ \\
\hline
\end{tabular}

The English monophthong open mid central long /3:/ for the sound occurring in the words like 'Bird' and 'Whril' is wrongly given as close mid central/ə:/ (ə- this symbol is known as schwa in IPA and this is the shortest and the most frequently used vowel in English language and this sound replaces many long and short vowels in connected speech).

Table 4.3.3. Pronunciation. Examples from Oxford English Sindhi Dictionary 2010 and Oxford Advanced learners dictionary.

\begin{tabular}{|c|c|c|c|}
\hline Word & Pronunciation in Sindhi & $\begin{array}{l}\text { IPA transcription given } \\
\text { Oxford English Sindhi } \\
\text { Dictionary } 2010\end{array}$ & $\begin{array}{l}\text { transcription given in } \\
\text { OALD } 9^{\text {th }} \text { Edition }\end{array}$ \\
\hline Pair & بينئُ & $/ \mathrm{p} \varepsilon: /$ & / peə(r) / \\
\hline Dare & بيسئ & /we: / & / deə(r) / \\
\hline Where & ويسئ & /we: / & / weə(r) / \\
\hline Wear & ويسئُ & /we: / & / weə(r) / \\
\hline
\end{tabular}

English monophthong open-mid front $/ \varepsilon$ :/ is used instead of diphthong/ ea/ in words like 'Wear' and 'Pair'.

Table 4.3.4. Pronunciation. Examples from Oxford English Sindhi Dictionary 2010 and Oxford Advanced learners dictionary.

\begin{tabular}{|c|c|c|c|}
\hline Word & $\begin{array}{r}\text { Iearner } \\
\text { Pronunciation in Sindhi }\end{array}$ & $\begin{array}{l}\text { IPA transcription given } \\
\text { Oxford English Sindhi } \\
\text { Dictionary } 2010\end{array}$ & $\begin{array}{l}\text { transcription given in } \\
\text { OALD } 9^{\text {th }} \text { Edition }\end{array}$ \\
\hline Height & هائت & / hsit / & / hait / \\
\hline Fight & فائِت & / f AIt $_{\text {/ }}$ & / fait / \\
\hline Bride & بر إئد & / bruId / & / brait / \\
\hline Tight & تَائتت & / thit / & / tait / \\
\hline
\end{tabular}

Diphthong / $/ \Lambda \mathrm{I}$ is used instead of /ar/ as in Tight and Fight. 
Table 4.3.5. Pronunciation. Examples from Oxford English Sindhi Dictionary 2010 and Oxford Advanced

\begin{tabular}{|c|c|c|c|}
\hline \multicolumn{4}{|c|}{ learners dictionary. } \\
\hline Word & Pronunciation in Sindhi & $\begin{array}{l}\text { IPA transcription given } \\
\text { Oxford English Sindhi } \\
\text { Dictionary } 2010\end{array}$ & $\begin{array}{l}\text { transcription given in } \\
\text { OALD } 9^{\text {th }} \text { Edition }\end{array}$ \\
\hline Fire & فِفائيَّ & /'fАІә / & /'faiə(r) / \\
\hline Liar & لائئَ & /'1ムІә / & /'laiə(r) / \\
\hline Dire & 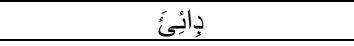 & /'dムIə / & /'daiə(r) / \\
\hline Buyer & بِائيًَ & / 'bムIə / & /'baiə(r) / \\
\hline
\end{tabular}

Triphthong / $\mathrm{\Lambda ә} /$ is used instead of /arə/ like in 'Dire' and 'liar'

\section{Discussion}

During the analysis related to the presentation of pronunciation in the dictionary, the researcher found that the transcription of certain words was not given correctly. This transcription, as discussed in the preface section of 'Oxford English-Sindhi dictionary', has been done with the help of unnamed software. The developers have just mentioned that they had done the analysis with the help of computer programming, which could be the reason that the transcription of the words has not been represented accurately in the dictionary. There are clear mistakes in the symbolic representation of phonemes related to an entry. That is to say the actual pronunciation of the words was different whereas their transcription was presented inaccurately. This particular finding of mispronunciation was also found by Shah.ZA and Mashori .G (2015). Another finding in this connection was related to the presentation of English pronunciation in Sindhi orthography. It was found that the pronunciation of the words in Sindhi could not match the actual pronunciation of English words. That is to say, English and Sindhi versions of the pronunciation of a single entry did not match each other.

\subsection{CONCLUSION}

The findings of the research are related to oxford English Sindhi Dictionary OESD2010. The dictionary was analyzed through content analysis. The results of the data show that meaning was presented very well but there was problem that the polysemous meanings were paraphrased. Similarly, symbols and abbreviations were also present in it but the problem was that all abbreviations as well as acronyms were not distinctively mentioned. There no clear boundary which could differentiate an acronym from an abbreviation.

Additionally, word classes were also mentioned in the dictionary. And, the dictionary is all well versed when it comes to the contexts of the usage of words. Finally, the pronunciation part was also found to be having errors which can also be called as misrepresentation of phonemes. In broader terms these phonemes were monophthongs, diphthongs and trip thongs.

\section{REFERENCES}

Akasu, K. (2013). Methods in dictionary criticism. In H. Jackson. (Ed.) (2013). The Bloomsbury companion to lexicography. London: Bloomsbury Academics.

Atkins, B. T, \& Rundell, M. (2008).The Oxford guide to practical lexicography. Oxford: Oxford University Press.

Bejoint, H. (2000) Modern lexicography: An introduction. sLondon: Oxford University Press.

Bergenholtz, H., \& Tarp, S. (2003). Two opposing theories: On H.E. Wiegand's recent discovery of lexicographic functions. Hermes, Journal of Linguistics, 31, 171-196.

Bergenholtz, H. 2012. What is a Dictionary? Lexikos 22: 20-30.Oslo: Universitetsforlaget.

Bergenholtz, Henning and Uwe Kaufmann. 1997. Terminography and Lexicography. A Critical Survey of Dictionaries from a Single Specialised Field. Tarp, S. (Ed.). 1997. Specialised Lexicography and Terminology. Hermes 18: 91-125.

Bergenholtz, Henning and Sven Tarp. 2003. Two Opposing Theories: On H.E. Wiegand's Recent Discovery of Lexicographic Functions. Hermes, Journal of Linguistics31:171-196.

Cohen, L., Lawrence. M., \& Morrison, K. (2011). Research methods in education. (7thed.) London: Routledge.

Cole, J. (2005). Sindhi. In Strazny, P. (Ed.) Encyclopedia of linguistics. New York: Routledge.

Cowie, A. P. (2009).The Oxford history of English lexicography. London: Clarendon Press.

Akasu, K. (2013). Methods in dictionary criticism. In H. Jackson. (Ed.) (2013). The Bloomsbury companion to lexicography. London: Bloomsbury Academics.

Atkins, B. T, \& Rundell, M. (2008).The Oxford guide to practical lexicography. Oxford: Oxford University Press.

Bejoint, H. (2000) Modern lexicography: An introduction. sLondon: Oxford University Press.

Bergenholtz, H., \& Tarp, S. (2003). Two opposing theories: On H.E. Wiegand's recent discovery of lexicographic functions. Hermes, Journal of Linguistics, 31, 171-196. 
Bergenholtz, H. 2012. What is a Dictionary? Lexikos 22: 20-30.Oslo: Universitetsforlaget.

Bergenholtz, Henning and Uwe Kaufmann. 1997. Terminography and Lexicography. A Critical Survey of Dictionaries from a Single Specialised Field. Tarp, S. (Ed.). 1997. Specialised Lexicography and Terminology. Hermes 18: 91-125.

Bergenholtz, Henning and Sven Tarp. 2003. Two Opposing Theories: On H.E. Wiegand's Recent Discovery of Lexicographic Functions. Hermes, Journal of Linguistics31:171-196.

Cohen, L., Lawrence. M., \& Morrison, K. (2011). Research methods in education. (7thed.) London: Routledge.

Cole, J. (2005). Sindhi. In Strazny, P. (Ed.) Encyclopedia of linguistics. New York: Routledge.

Cowie, A. P. (2009). The Oxford history of English lexicography. London: Clarendon Press.

Shahani, T. A. (1939) The English-Sindhi Dictionary, Sukkur: Ajaib Stores.

Sindhica Dictionary (2003), Karachi: Sindhica Academy.

Shah, Z. A (2007). Developments in Sindhi lexicography: a historical descriptive survey of bilingual English Sindhi dictionary. Unpublished M. Phil thesis. Multan: Bahauddin Zakariya University.

Shah, Z. A., \& Khand, Z. (2009). Developments in Sindhi lexicography: A descriptive survey of bilingual English-Sindhi dictionary. ELF Annual Research Journal, (11), 21-50.

Shah, Z. \& Khand, Z. (2008). Early attempts in Sindhi lexicography: A descriptive survey of bilingual EnglishSindhi dictionary before 1947 ELF Annual Research Journal, 9, 39-71.

Shah, Z. A., \& Mashori, G. M. (2011). Oxford English-Sindhi dictionary: A critical study in lexicography. ELF Annual Research Journal. 13, 37-46. 